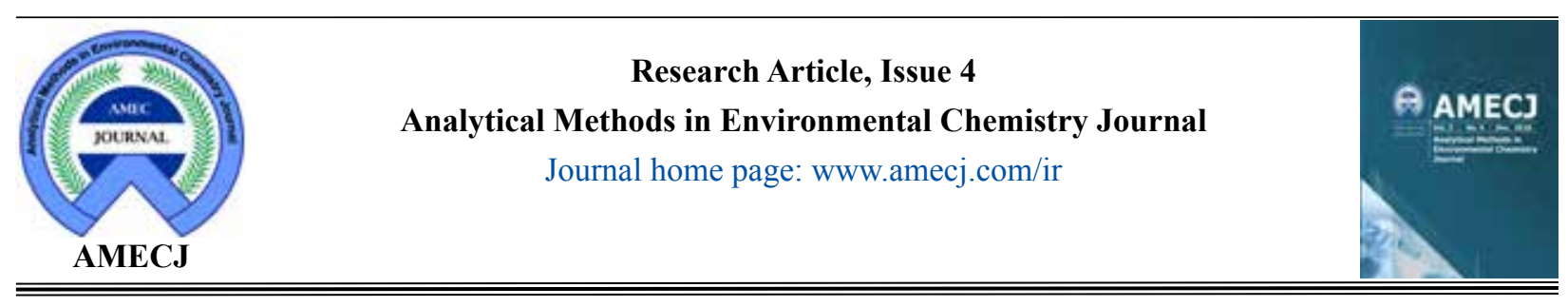

\title{
Sulfamethizole functionalized graphene oxide for in- vitro separation and determination lead in blood serum of battery manufactories workers by syringe filter-dispersive- micro solid phase extraction
}

\author{
Abhijit De ${ }^{a,}$ and S. Mojtaba Mostafavi ${ }^{b}$ \\ ${ }^{a}$ HITech institute of theoretical and computational chemistry, Shivakote, Hesaraghatta Hobli, Bengaluru, India \\ ${ }^{b}$ Department of Chemistry, Iranian-Australian Community of Science, Hobart, University of Tasmania, Australia
}

\begin{tabular}{l} 
A R T I C L E I N F O : \\
Received 18 Aug 2020 \\
Revised form 24 Oct 2020 \\
Accepted 14 Nov 2020 \\
Available online 29 Dec 2020 \\
\hline \hline---- \\
Keywords: \\
Lead, \\
Human blood/serum, \\
Sulfamethizole, \\
Nano graphene oxide, \\
Syringe filter, \\
Dispersive-micro solid phase extraction \\
procedure
\end{tabular}

A R T I C L E I N F O :

Received 18 Aug 2020

Revised form 24 Oct 2020

Accepted 14 Nov 2020

Available online 29 Dec 2020

Keywords:

Lead,

Human blood/ser

Syringe filter,

procedure

\begin{abstract}
A B S T R A C T
The toxic effect of lead $(\mathrm{Pb})$ causes to anemia and iron deficiency in human body. So, the lead determination in blood/serum samples is very important. In this study, a novel adsorbent based on sulfamethizole functionalized on nanographene oxide $\left(\mathrm{C}_{3} \mathrm{H}_{10} \mathrm{~N}_{4} \mathrm{O}_{2} \mathrm{~S}_{2}-\mathrm{NGO}\right.$; SM$\mathrm{NGO}$ ) was used for extraction of $\mathrm{Pb}$ (II) from human blood, serum and plasma samples in battery manufactories workers by syringe filterdispersive-micro solid phase extraction procedure (SF-D- $\mu-S P E)$. By procedure, $25 \mathrm{mg}$ of SM-NGO mixed with $10 \mathrm{~mL}$ of human blood/ serum or plasma samples and aspirated by $10 \mathrm{~mL}$ of syringe tube. After sonication of samples for $5 \mathrm{~min}$, the $\mathrm{Pb}$ ions adsorbed based on sulfur of SM-NGO adsorbent at $\mathrm{pH}=6$ and the solid phase separated by syringe coupled to Millex-FG hydrophobic PTFE membrane $(0.2 \mu \mathrm{m})$. Then, the lead ions were back-extracted from SM-NGO/ PTFE by elution phase with $0.5 \mathrm{~mL}$ of nitric acid solution $(0.5 \mathrm{M})$. Finally, the concentrations of $\mathrm{Pb}(\mathrm{II})$ ions were determined by atom trap flame atomic absorption spectrometry (AT-FAAS) after dilution with DW up to $1 \mathrm{~mL}$. After optimization, the linear range (LR), LOD and enrichment factor (EF) for $\mathrm{Pb}$ ions was obtained, 10-500 $\mu \mathrm{g}$ $\mathrm{L}^{-1}, 2.5 \mu \mathrm{g} \mathrm{L}^{-1}$ and 9.86, respectively. The validation of procedure was confirmed by electhermal atomic absorption spectrophotometer (ET-AAS) and certified reference material (NIST, CRM) in human samples.
\end{abstract}

\section{Introduction}

Heavy metals intakes to human body from air, water and foods. Heavy metals such as lead $(\mathrm{Pb})$, chromium $\left(\mathrm{Cr}_{\mathrm{VI}}\right)$ and mercury $(\mathrm{Hg})$ cause to serious problem in humans and depended on way entrance

\footnotetext{
*Corresponding Author: Abhijit De

Email: abhijit@iitcc.org, ade@actrec.gov.in

https://doi.org/10.24200/amecj.v3.i04.124
}

(Skin, lungs and gastrointestinal system) and concentrations [1-3]. The battery manufactories, gasoline, wastewater, $\mathrm{x}$-ray protection and paint are main source of lead in environment [4,5]. The battery factories are a main source of lead toxicity in workers and cause to dysfunction in blood red cells, the central nervous system tissues (CNST), bones and renal tissues [6]. Also, the lead poisoning can 
be effected on human organs such as braine, renal, liver and bone $[7,8]$. The lead complexes in human body create by interaction of lead with proteins/ amino acids and cause anemia $[9,10]$. On the other hand the lead exposure causes to decrease the erythrocytes cells (RBC) and reducing biosynthesis of hemoglobin. The occupational safety and health administration (OSHA) has reported that the exposure lead $(\mathrm{Pb})$ more than $600 \mu \mathrm{g} \mathrm{L}^{-1}$ is toxic and workers must be offline from work and return to work when the BLL is below $300 \mu \mathrm{g} \mathrm{L}^{-1}$. Also, the food and drug administration (FDA) has announced the normal range of $\mathrm{Pb}$ in human blood is below 250-300 $\mu \mathrm{g} \mathrm{L}^{-1}$ [11]. The limit exposure of lead $(\mathrm{Pb})$ in air is considered about $50 \mu \mathrm{g} \mathrm{m}^{-3}$ by NIOSH [12]. Due to lead toxicity in human, the accurate technology need to use for determination of lead ions in the human blood/ serum samples. Recently, the various methods were reported for lead determination in human biological samples. The instrumental techniques such as the electrothermal atomic absorption spectrometry (ET-AAS) [13,14], the inductively coupled plasma - atomic emission spectroscopy or mass spectrometry (ICP-AES/MS) [16], the high-performance liquid chromatographic (HPLC) and the isotope dilution inductively coupled plasma mass spectrometry (ID-ICP-MS) were used for lead determination in different matrixes[17]. Moreover, the sample preparation method is required for extracting of lead ions in different biological samples before determination by spectrometry techniques. Various sample preparation method such as liquid-phase microextraction or dispersive liquid-liquid microextraction (DLLME) [18,19], hydrophobic deep eutectic solvents based on microextraction techniques[20], the headspace solid-phase microextraction [21], the carriermediated hollow fiber liquid phase microextraction [22], the dispersive solid-phase extraction (DSPE) combined with ultrasound-assisted emulsification microextraction based on the solidification of floating organic drop (UAEME-SFO)[23], the microextraction based on precipitation[24], the magnetic solid-phase extraction (MSPE) [25], and dispersive-micro solid phase extraction procedure
(D- $\mu$-SPE) [26], were used for lead determination in different human matrixes. Between them, D- $\mu$ SPE procedure is used in different matrixes by researchers. In addition, the characterizations of sorbents are important factor for lead extraction by the SPE method. For examples, the adsorbents such as, the silica aerogel nanoadsorbent [27], the magnetic phosphorus-containing polymer [28 ], the magnetic metal organic frameworks MMOF[29], the carboxylated graphene [30], the graphene Oxide Sheets [31], and modified-carbon nanotubes with $\mathrm{NiFe}_{2} \mathrm{O}_{4}$ [32] were reported by chemistry and nanochemistry scientists. The previously works showed that the different pretreatment techniques based on metal nanoparticles, the drugs, the functionalization of CNTs or GO, the magnetic nanoparticles can be increased the efficient extraction of heavy metals in human samples. Recently, some drugs use for in-vitro and in-vivo extraction of heavy metal in human samples and depend on structure and function groups. The antibiotic of sulfamethizole (SM) is a drug and use as an insistent inhibitor of bacterial enzyme. The SM can be complexed with metals in human body and depended on $\mathrm{pH}$ and covalence bonding.

In this study, a new SM-NGO adsorbent was used for determination lead in blood/serum samples by syringe filter-dispersive-micro solid phase extraction procedure (SF-D- $\mu$-SPE) at $\mathrm{pH}=6.0$. The high recovery and absorption capacity for lead extraction was obtained in optimized conditions. The lead concentrations in blood/serum samples were determined by AT-FAAS after sample pretreatment.

\section{Experimental}

\subsection{Instrumental}

Lead in human blood and serum samples determined by the GBC906 atom trap flame atomic absorption spectrophotometer (AT-FAAS, AUS) after sample preparation. The atom trap accessory put on burner and the fuel gas (air-acetylene), lamp position, slit and light line were manually tuned. Other parameters such as current and silt adjusted by Avanta Software. The minimum sample volume 
(0.5-1 mL) vacuumed by nebulizer of AT-FAAS after adjusting flow rate of sample $\left(\mathrm{mL} \mathrm{min}^{-1}\right)$. The LOD for $\mathrm{Pb}$ determination with AT-FAAS and F-AAS in standard solutions was obtained $0.025 \mathrm{mg} \mathrm{L}^{-1}$ and $0.07 \mathrm{mg} \mathrm{L}^{-1}$, respectively. The linear ranges of 0.08-6.0 mg L-1 and 0.25-6.0 mg $\mathrm{L}^{-1}$ were obtained for AT-FAAS and F-AAS at wavelength of $283.3 \mathrm{~nm}(5 \mathrm{~mA})$. All samples were injected with an auto-sampler injector from 100 $\mu \mathrm{L}$ to $1000 \mu \mathrm{L}$. The Inductively coupled plasma mass spectrometry (ICP-MS, Perkin Elmer, Main Plasma Gas: Ar flow $\sim 15 \mathrm{~L} \mathrm{~min}^{-1}, 1.2 \mathrm{~s} / \mathrm{m}$, USA) as high sensitive analyzer was used for determining of $\mathrm{Pb}$ in real human samples after microwave digestion. ICP-MS atomizes the liquid sample and generate atomic ions $\left(\mathrm{M} \rightarrow \mathrm{M}^{+}+\mathrm{e}^{-}\right)$, which are then detected by quadrupole-based mass analyzer system (mass-to-charge ratio (m/z), ICP-Q-MS). Before mass separation, a beam of positive ions has to be extracted from the plasma and focused into the mass-analyzer. The $\mathrm{pH}$ meter was used for determining of $\mathrm{pH}$ in liquid samples (Metrohm E-744). The vortex mixer (Thermo, USA) with 100-500 rpm, ultrasonic heating (Iran) and Falcon centrifuging (1000-4500rpm) prepared for this study.

\subsection{Reagents and Materials}

The lead standard solution $\left(\mathrm{Pb} ; 1000 \mathrm{mg} \mathrm{L}^{-1}\right.$ in $2 \%$ nitric acid) was purchased from Sigma (Germany). All standard of lead $(0.08,0.1,0.2,0.5,1,2,5$ $\left.\mathrm{mg} \mathrm{L}^{-1}\right)$ prepared by dilution of the stock lead solution (1000 $\mathrm{mg} \mathrm{L}^{-1}$ ) with ultrapure water (UPW, Millipore, USA). Also, the sub-ppb concentration (10-500 $\mu \mathrm{g} \mathrm{L}^{-1}$ ) prepared by dilution of stock lead standard solution $\left(1 \mathrm{mg} \mathrm{L}^{-1}\right)$. The pure reagents such as, the polyoxyethylene octyl phenyl ether (TX100), nitric acid $\left(\mathrm{HNO}_{3}\right), \mathrm{HCl}$, acetone, and ethanol were purchased from Sigma Aldrich, Germany. Sulfamethizole (4-Amino- $N$-(5-methyl-1,3,4thiadiazol-2-yl) enzenesulfonamide; $\mathrm{C}_{9} \mathrm{H}_{10} \mathrm{~N}_{4} \mathrm{O}_{2} \mathrm{~S}_{2}$; CASN:144-82-1) and the hydrophobic ionic liquid of 1-methyl-3-octylimidazolium hexafluorophosphate. ([OMIM] PF6; $\mathrm{C}_{12} \mathrm{H}_{23} \mathrm{~F}_{6} \mathrm{~N}_{2} \mathrm{P}$; CASN: 304680-36-2) was purchased from Sigma
Aldrich, Germany. The GO and GO-COOH was prepared from chemistry department, India. The $\mathrm{pH}$ was adjusted to 6 by sodium phosphate buffer solution $\left(\mathrm{Na}_{2} \mathrm{HPO}_{4} / \mathrm{NaH}_{2} \mathrm{PO}_{4}\right)$ from Merck (Germany).

\subsection{Sample preparations}

All glasses such as vials, volumetric, dishes and beakers cleaned with $\mathrm{HNO}_{3}$ and $\mathrm{H}_{2} \mathrm{SO}_{4}$ solution $(1: 1,2 \mathrm{M})$ for at least $12 \mathrm{~h}$. After cleaning, all of glasses washed for 10 times with DW. The normal $\mathrm{Pb}$ values in blood samples have less than $250 \mu \mathrm{g} \mathrm{L}^{-1}$ or $>25 \mu \mathrm{g} \mathrm{dL}^{-1}$ and more than $500 \mu \mathrm{g}$ $\mathrm{L}^{-1}$ is toxic. By procedure, $10 \mathrm{~mL}$ of the blood or serum samples were prepared from 50 workers of lead-acid batteries factories in India (Men, 20-55 age). The sterilized syringes were used for blood samples. The pure heparin based on free of $\mathrm{Pb}$ was prepared and injected to blood. The blood samples were maintained at $-5{ }^{\circ} \mathrm{C}$. In this work, all blood samples prepared based on the world medical association declaration of Helsinki for physicians in human and all blood samples prepared from worker with agreement forms.

\subsection{Synthesis of GO@ Sulfamethizole \\ 2.4.1.Preparation of $G O$}

The graphene oxide (GO) was prepared with pure graphite $(\mathrm{G})$ by modified hummers procedure [33]. The $0.2 \mathrm{~g}$ of graphite powder was added into mixing solution $\left(\mathrm{H}_{2} \mathrm{SO}_{4} / \mathrm{H}_{3} \mathrm{PO}_{4} ; 9: 1\right)$ and then potassium permanganate $\left(\mathrm{KMnO}_{4}, 1.3 \mathrm{~g}\right)$ was slowly added by stirring solution up to became black green. The $\mathrm{H}_{2} \mathrm{O}_{2}$ slowly added to solution and stirred for removal of excess of $\mathrm{KMnO}$. After cooling, the hydrochloric acid ( $\mathrm{HCl}: 10 \mathrm{~mL}$ in $30 \mathrm{~mL} \mathrm{DW})$ was added and centrifuged. Then, the powder product of $\mathrm{GO}$ was washed with $\mathrm{HCl}$ and $\mathrm{DW}$ for 5 times and dried at $90{ }^{\circ} \mathrm{C}$ for 1 day.

\subsubsection{Synthesis of GO@Cl}

Chlorinated graphene oxide was prepared due to the Liu procedure [34]. First, $1.0 \mathrm{~g}$ of GO, $20 \mathrm{ml}$ of benzene, and $100 \mathrm{ml}$ of $\mathrm{SOCl}_{2}$ were added in a $100-\mathrm{ml}$ round flask and stirred $\left(60-70{ }^{\circ} \mathrm{C}\right)$. Then, 
the excess of $\mathrm{SOCl}_{2}$ was exit out from mixture by distillation process based on vacuum condition. The solid product put in acetone and the suspension in acetone was filtered with Watman filter (200 $\mathrm{nm})$. Finally, the product washed with acetone for 3 times and dried at $60^{\circ} \mathrm{C}$.

\subsubsection{Synthesis of Sulfamethizole functionalized on nanographene oxide (SM@NGO)}

$1 \mathrm{~g}$ of sulfamethizole (SM) solved in $20 \mathrm{~mL}$ $\mathrm{H}_{2} \mathrm{O}$ with $5 \mathrm{~mL}$ of $\mathrm{NaOH}$ and then $1 \mathrm{~mL}$ of $\mathrm{SM}$ solution were mixed in $60 \mathrm{~mL}$ ethanol $(99 \%)$ by an ultrasonic bath $(25 \mathrm{~min})$ in a $100 \mathrm{~mL}$ round bottom flask. Then, $0.1 \mathrm{~mL}$ of triethylamine was added to mixture, and the mixture was refluxed at $70{ }^{\circ} \mathrm{C}$ for 5 hours. The obtained product was separated from the mixture by a hydrophobic PTFE Membrane Filters (polytetrafluoroethylene) for filtering SM@NGO. The SM@NGO product washed with ethanol for many times and finally dried under vacuum at $95^{\circ} \mathrm{C}$.

\subsection{Extraction Procedure}

By the SF-D- $\mu$-SPE procedure, $10 \mathrm{~mL}$ of serum and plasma samples were used for determination of lead ions. Firstly, 25 mg of SM@NGO added to human blood/serum and lead standard solution (10-500 $\mu \mathrm{g}$ $\left.\mathrm{L}^{-1}\right)$ at $\mathrm{pH}=6.0$ and aspirated by $10 \mathrm{~mL}$ of syringe tube. The syringe tube placed on shaking tube for $5.0 \mathrm{~min}$, after shaking, the lead was extracted by the sulfur group of SM@NGO in optimized pH $\left(\mathrm{Pb}^{2+} \rightarrow\right.$ : SR@GO). The SM@NGO separated from liquid phase by syringe hydrophobic PTFE membrane. Then, the $\mathrm{pb}^{2+}$ ions back-extracted from SM@NGO-PTFE membrane with elution of nitric acidic $(0.5 \mathrm{~mL}, 0.5 \mathrm{M})$ and remain solution was determined by AT-FAAS after dilution with DW up to $1 \mathrm{~mL}$ (Fig.1). The procedure run for 10 blank solutions without any lead. The calibration curve of lead based on SF-D- $\mu$-SPE/AT-FAAS procedure (10-500 $\left.\mu \mathrm{g} \mathrm{L}^{-1}\right)$ and standard method by AT-FAAS (0.1- $\left.5 \mathrm{mg} \mathrm{L}^{-1}\right)$ were done. The enrichment factor (EF) calculated by curve fitting rules $\left(\operatorname{Tg} a=m_{1} / m_{2}\right)$.

\section{Results and discussion}

\subsection{Mechanism of Extraction by SM@NGO}

The pure sulfamethizole drug was solved in $\mathrm{H}_{2} \mathrm{O} / \mathrm{NaOH}$ solutions and then mixed with ethanol $(99 \%)$ by an ultrasonic bath. Then, the triethylamine were added to mixture. After reflux, the SM@NGO product was separated from the mixture by PTFE membrane by washing and drying. Finally, the sulfamethizole functionalized on nanographene oxide caused to make favorite adsorbent based on sulfur group (dative bond) for lead extraction in blood, serum and plasma samples

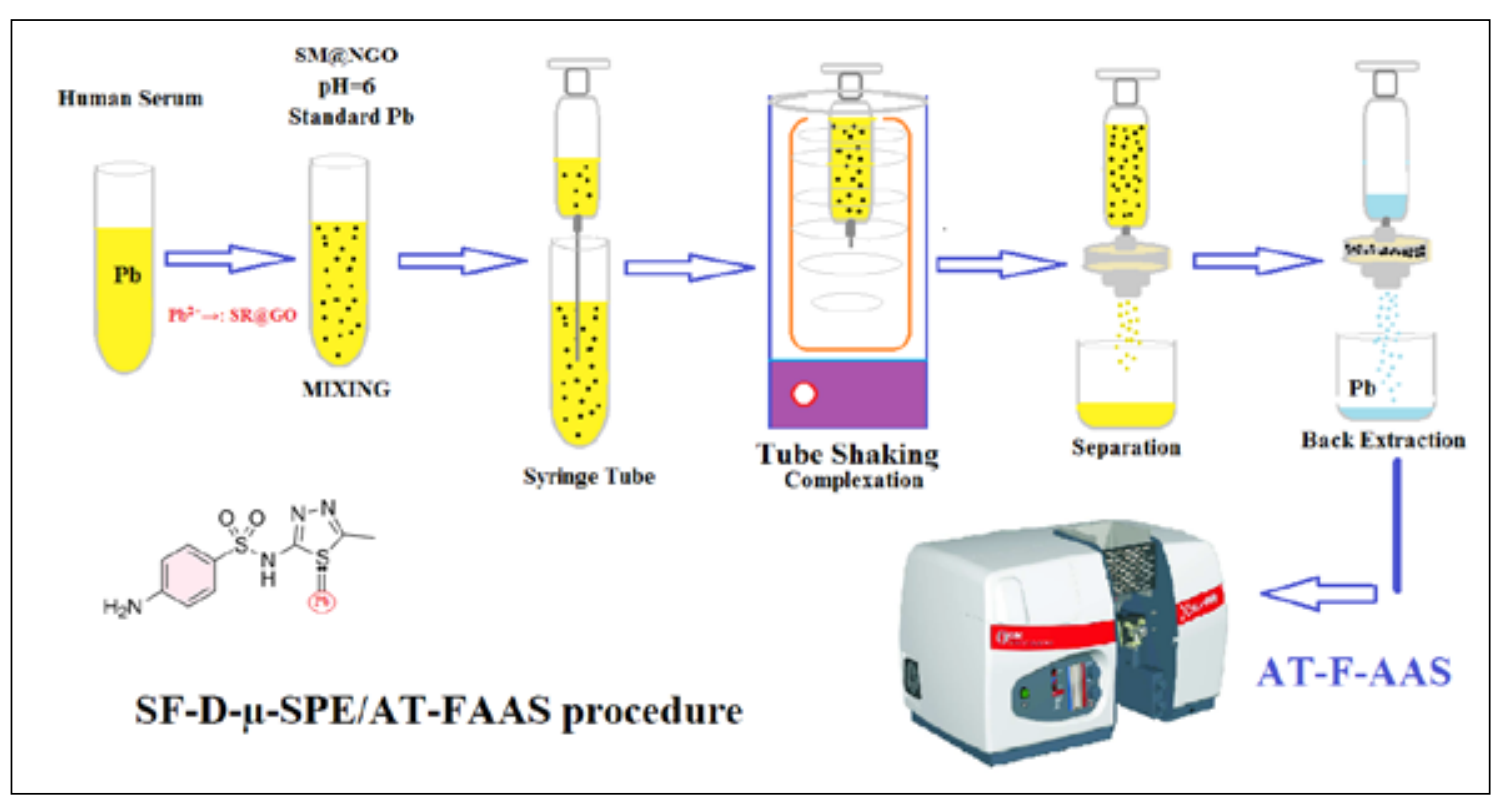

Fig. 1. The SF-D- $\mu$-SPE procedure for extraction of lead in human samples 


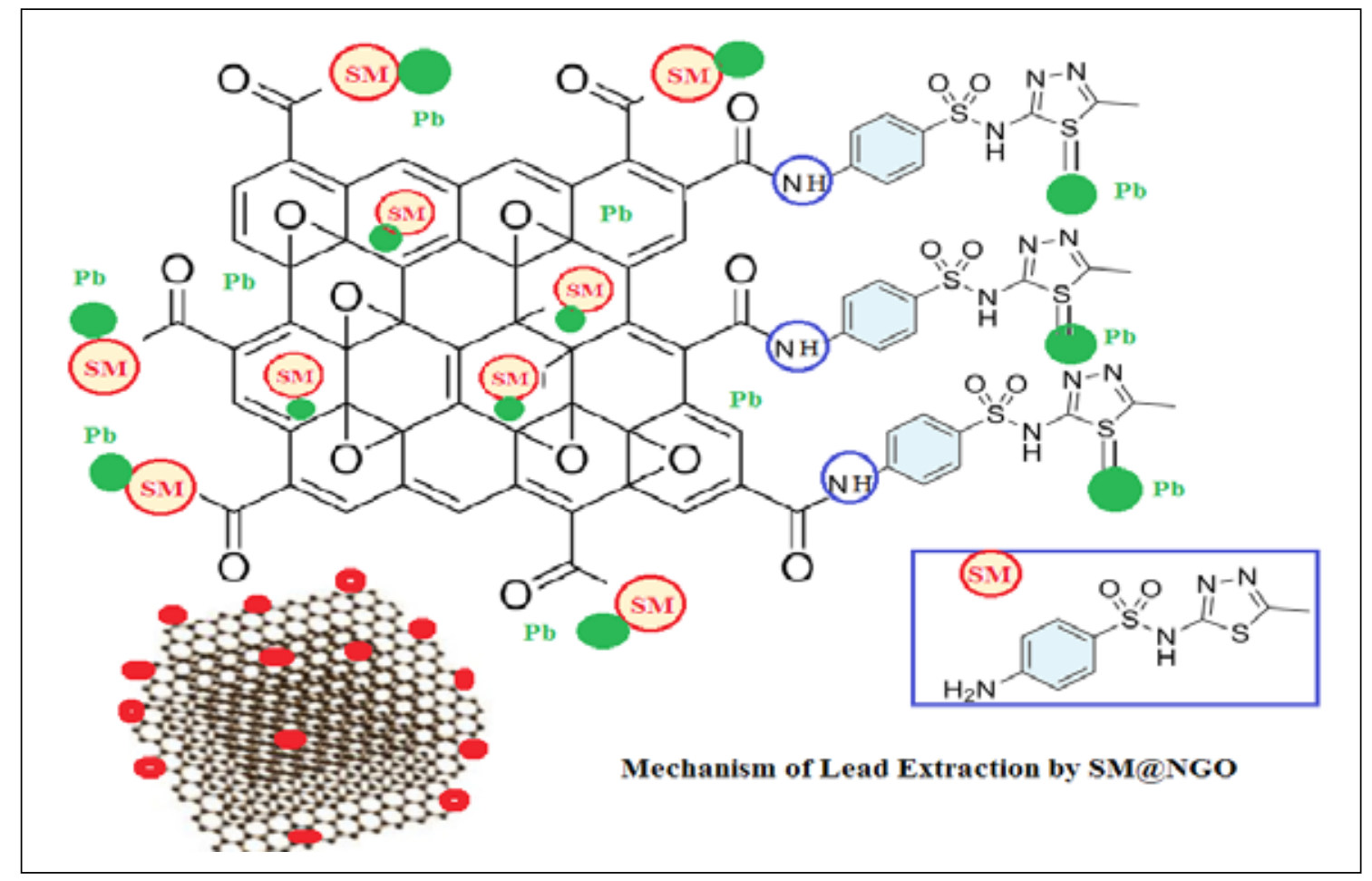

Fig.2. The mechanism of lead extraction in blood/serum samples based on SM@NGO by the SF-D- $\mu$-SPE procedure

with high recovery. Therefore, the lead adsorption/ extraction with SM@NGO nanostructure caused to increase the recovery up to $98.5 \%$ as compared to NGO adsorbent $(26.4 \%)$. The results showed, the mechanism of lead extraction in serum, blood and plasma samples depended on sulfur group of sulfamethizole in SM@NGO adsorbent at optimized pH (Fig.2).

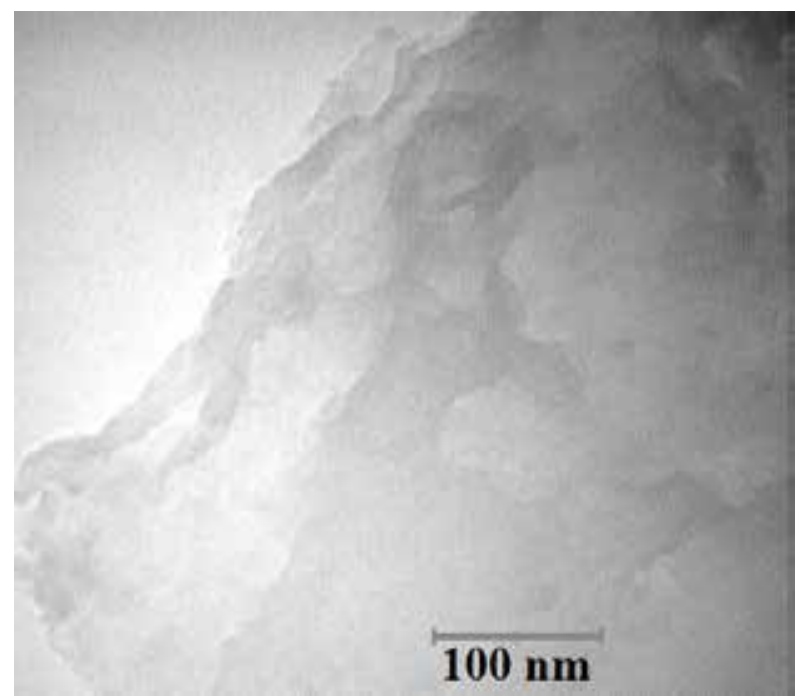

Fig.3. The TEM of SM@NGO adsorbent

\subsection{SEM, TEM and FTIR of SM@NGO}

The NGO adsorbent was synthesized from graphite powder according to the modified Hummer>s method from RIPI Company (Iran) [33] and used for synthesis of SM@NGO. The TEM and SEM of SM@NGO showed the minimum size between 30-100 nm which were shown in Figures 3 and 4, respectively. The FT-IR spectrum of NGO-COOH

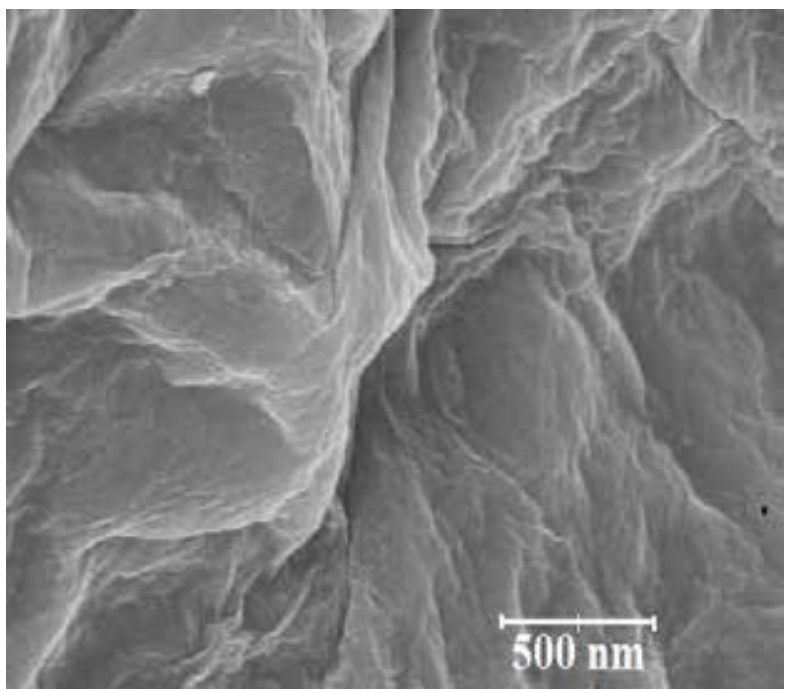

Fig.4. The SEM of SM@NGO adsorbent 
and SM@NGO adsorbent was shown in Figure 5. Based on FT-IR spectrum, the $\mathrm{C}=\mathrm{N}$ double bond is about twice as strong as a $\mathrm{C}-\mathrm{N}$ single bond, and the $\mathrm{C} \equiv \mathrm{N}$ triple bond is similarly stronger than double bond. The infrared stretching frequencies of these groups vary in the same order, ranging from $1100 \mathrm{~cm}^{-1}$ for $\mathrm{C}-\mathrm{N}$, to $1660 \mathrm{~cm}^{-1}$ for $\mathrm{C}=\mathrm{N}$. Also, symmetric and a symmetric traction for sulfur bond (S-C) ranging from $1135-1165 \mathrm{~cm}^{-1}$ and1310-1360 $\mathrm{cm}^{-1}$ were seen. The $\mathrm{O}-\mathrm{H}$ bond is about $3600 \mathrm{~cm}^{-1}$, $\mathrm{S}-\mathrm{H}$ bond in $2570 \mathrm{~cm}^{-1}$, C-H bond in $3000 \mathrm{~cm}^{-1}$ and $\mathrm{N}-\mathrm{H}$ bond in $3400 \mathrm{~cm}^{-1}$ observed.

The X-ray diffraction (XRD) of NGO and SM@ NGO were shown in Figure 6. XRD of graphene
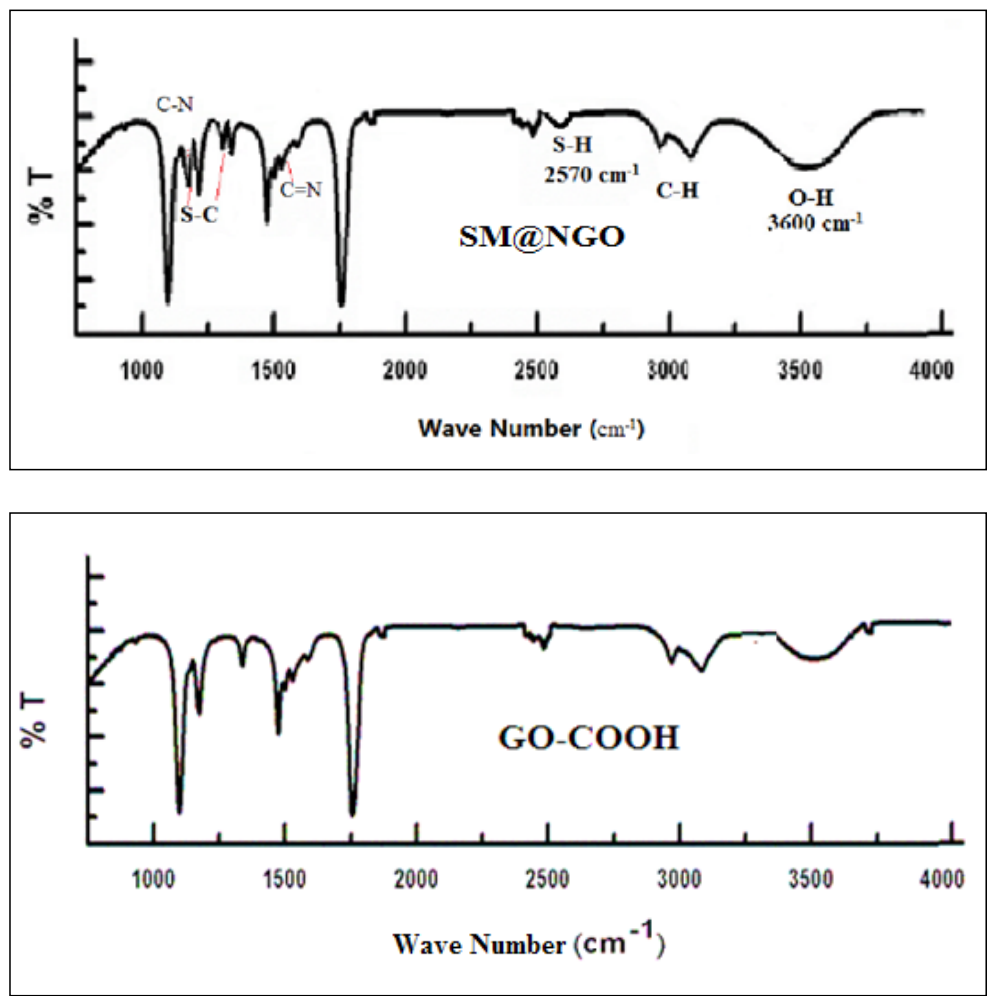

Fig.5. The FT-IR spectrum of NGO-COOH and SM@NGO adsorbent

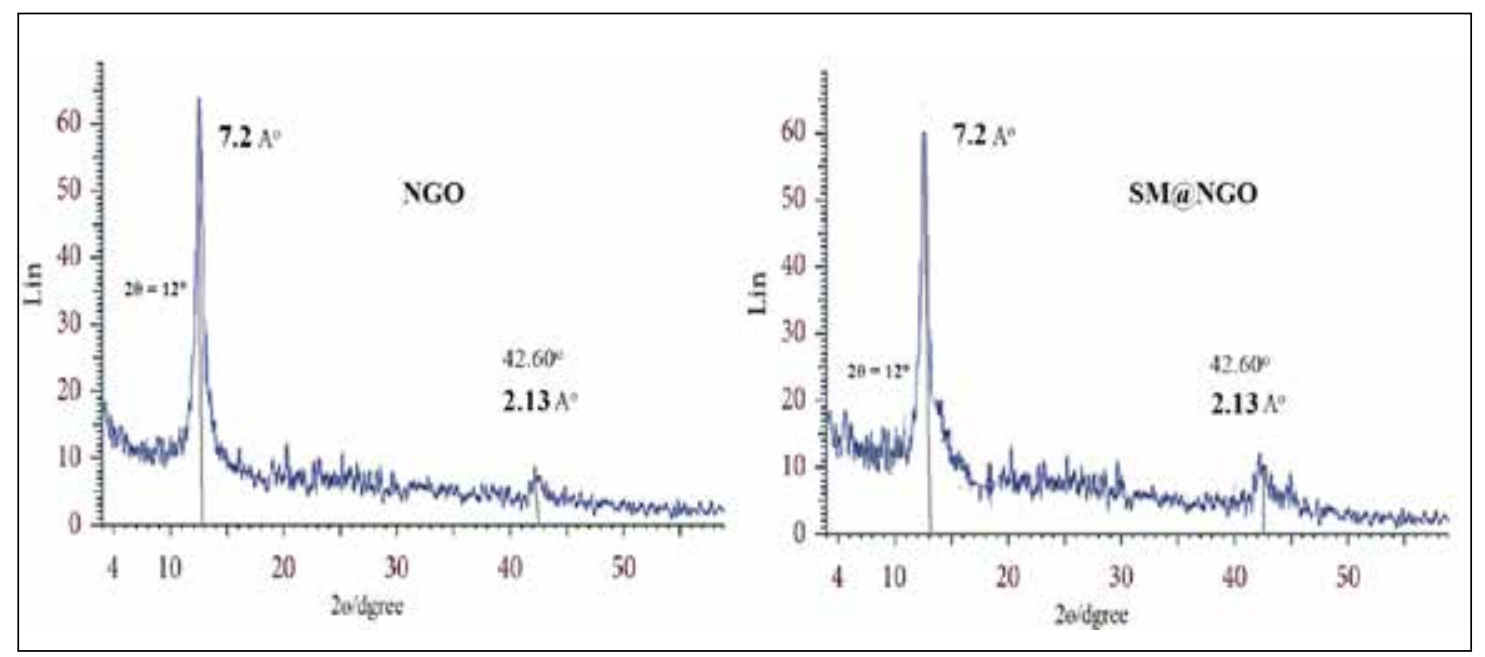

Fig.6. The X-ray diffraction (XRD) for NGO and SM@NGO adsorbents 
oxide shows the one main diffraction peak at $2 \theta=12^{\circ}$ related to the oxygen groups which are intercalated between graphene sheets. The peaks at $2 \theta=12^{\circ}$ and $42.60^{\circ}$ are related to the diffraction planes of (002) and (100) respectively, which can be showed in both of the XRD of GO and SM@NGO.

\subsection{Optimization of extraction parameters}

The SF-D- $\mu$-SPE procedure based on new SM@ NGO adsorbent was used for the extraction and determination $\mathrm{Pb}$ (II) ions in serum and plasma samples. For efficient lead extraction, the analytical parameters such as $\mathrm{pH}$, sample volume and amount of SM@NGO adsorbent were optimized.

\subsubsection{Influence of $\mathrm{pH}$}

The efficient extraction of lead in blood serum of battery workers was depended to $\mathrm{pH}$. So, the $\mathrm{pH}$ of samples must be examined and optimized. The $\mathrm{pH}$ can be affected on increasing/decreasing extraction processes of lead in serum samples. The buffer solutions help us to improved extraction recovery by adjusting $\mathrm{pH}$. Therefore, the different value of $\mathrm{pH}$ between 2-10 was evaluated by lead concentration from 10 to $500 \mu \mathrm{g} \mathrm{L}^{-1}$. The results showed, the high extraction of lead ions in human biological samples was obtained at pH of 6.0 by SM@NGO adsorbent. On the other hand, the recoveries can be decreased at acidic or basic $\mathrm{pH}$. So, the $\mathrm{pH}$ point of 6 was used for extraction $\mathrm{Pb}$ in real samples (Fig.7). Based on extraction mechanism, the coordination of dative bond of sulfur as negative charge in SM@ NGO with the positively charged of $\mathrm{Pb}^{2+}$ were happened in optimized $\mathrm{pH}$. At low $\mathrm{pH}$ (less than 5.5), the SM@NGO adsorbent protonated and surface of adsorbent got the positively charged. Due to the electrostatic repulsion, the recoveries of lead extraction were decreased. Moreover, in optimized $\mathrm{pH}(6)$, the surface of SM@NGO have negatively charged and high recovery was obtained for $\mathrm{Pb}^{2+}$ ions by the SF-D- $\mu$-SPE procedure (more than $96 \%$ ).

\subsubsection{Influence of SM@NGO amount}

The amount of SM@NGO nanoparticles for lead extraction in human samples has studied with lead concentration between 10-500 $\mu \mathrm{g} \mathrm{L}^{-1}$ as a low and high LOQ ranges. For this proposed, 1-50 mg of SM@NGO adsorbent were used for lead extraction in serum, blood, plasma and standard solutions by the SF-D- $\mu$-SPE method. The obtained results showed that the maximum of lead extraction in human samples was achieved for 22 mg of SM@ NGO nanostructure. So, $25 \mathrm{mg}$ of SM@NGO adsorbent was used for further work (Fig. 8). The extra mass of $25 \mathrm{mg}$ had no effect on recovery of lead extraction in human samples.

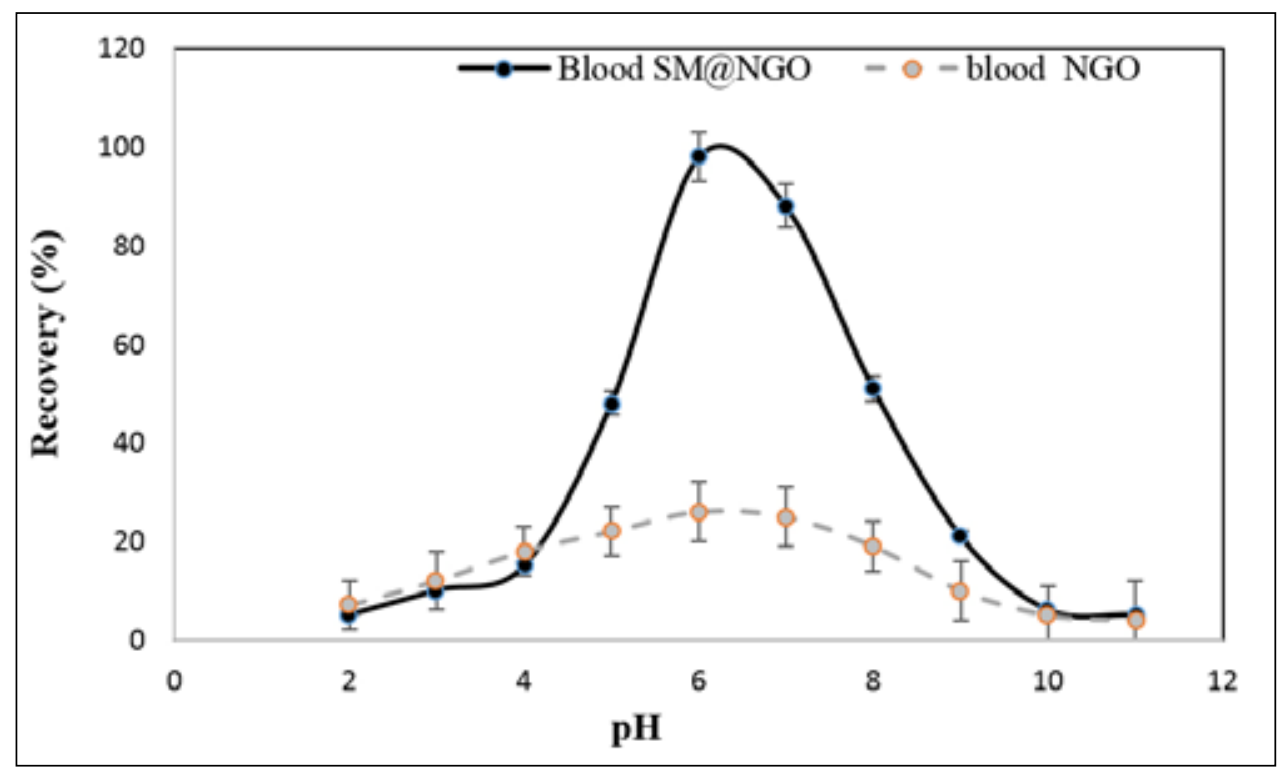

Fig.7. The influence of pH on lead extraction based on SM@NGO adsorbent by the SF-D- $\mu-\mathrm{SPE}$ procedure 


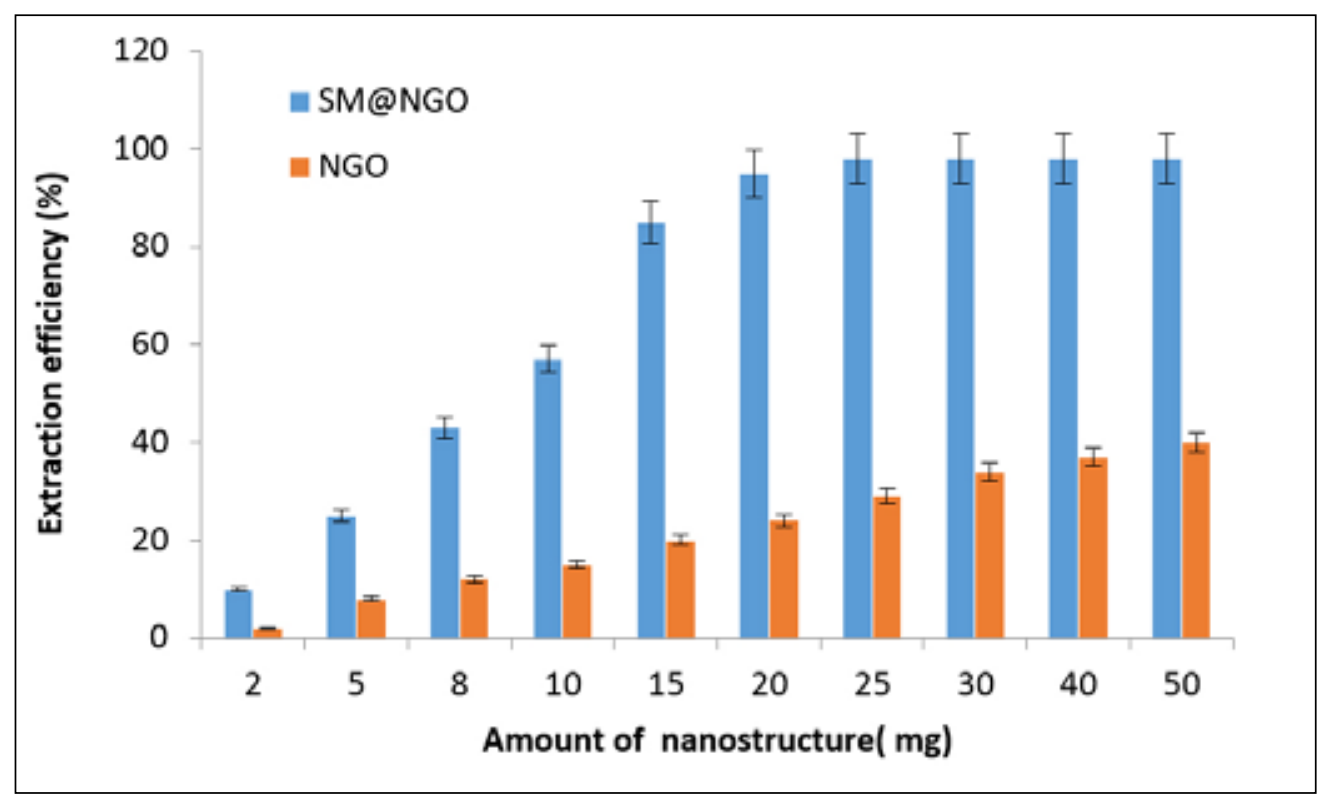

Fig.8. The influence of amount of SM@NGO on lead extraction by the SF-D- $\mu$-SPE procedure

\subsubsection{Influence of sample volume}

Sample volume is an effective parameter for extraction lead ions in human biological samples such as serum, blood and plasma. So, the lead extraction for sample volume between 1-30 mL was studied and optimized with the low and high LOQ concentration ranges (10-500 $\left.\mu \mathrm{g} \mathrm{L}^{-1}\right)$ by the SF-D-
$\mu$-SPE method (Fig. 9). The experimental results confirmed that the best extraction was obtained for less than $15 \mathrm{~mL}$ of human samples. Therefore, $10 \mathrm{~mL}$ was selected as optimum volume of human samples for lead extraction with 25 mg of SM@NGO adsorbent at $\mathrm{pH}=6$. The recovery was decreased by adding sample volume in optimized conditions.

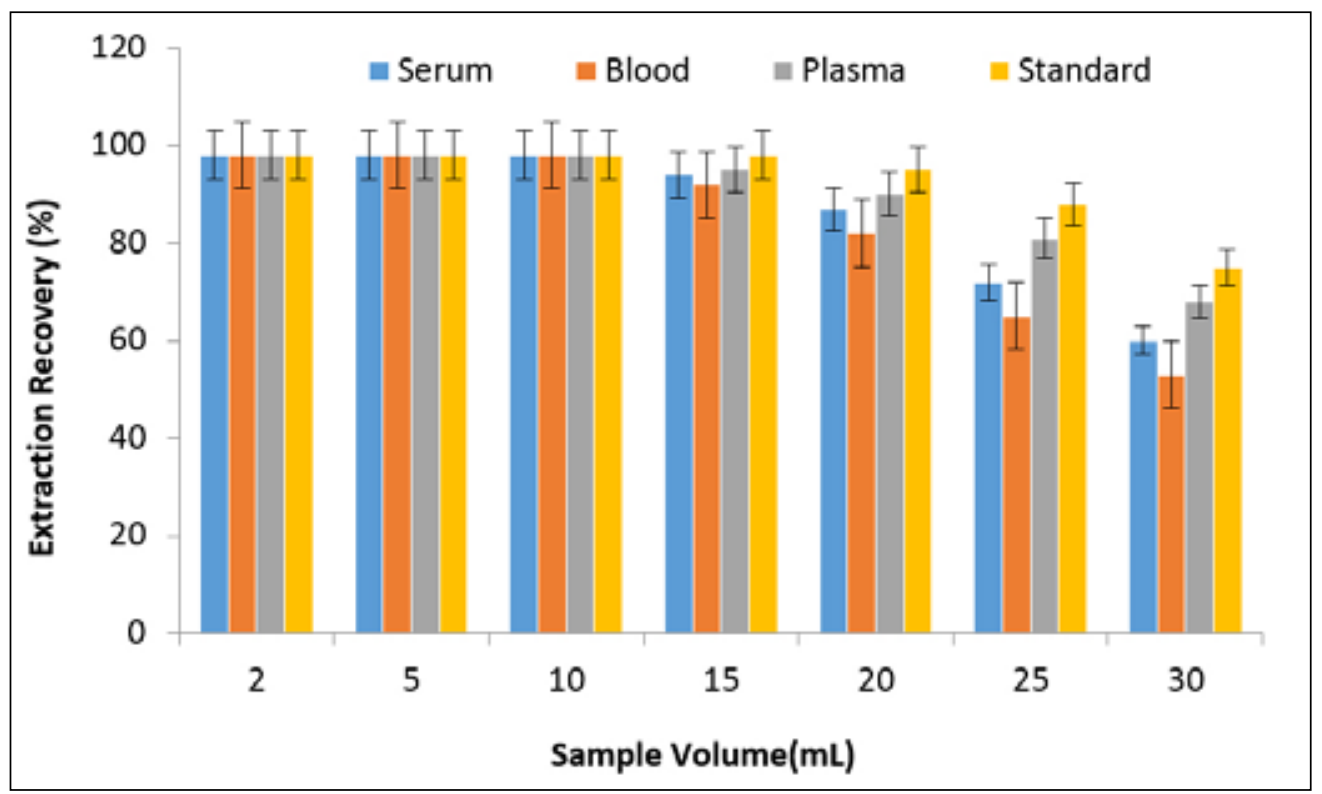

Fig.9. The influence of sample volume on lead extraction based on SM@NGO adsorbent by the SF-D- $\mu$-SPE procedure 


\subsubsection{Influence of volume and concentration of eluents}

The influence of volume and concentration of eluents such as $\mathrm{HCl}, \mathrm{HNO}_{3}, \mathrm{NaOH}$ and $\mathrm{CH}_{3} \mathrm{COOH}$ for back-extraction of lead ions from solid phase were studied and optimized by SF-D$\mu$-SPE procedure. The syringe coupled to MillexFG hydrophobic PTFE membrane $(0.2 \mu \mathrm{m})$ was used for back-extraction lead from adsorbent by different volume of eluents between $0.5-2 \mathrm{~mL}$ (0.2-1 M). After pushing the plunger of syringe, the elution of SM@NGO/hydrophobic PTFE membrane was performed by different eluents. In acidic or basic $\mathrm{pH}$, the lead $(\mathrm{Pb})$ released from SM@NGO/PTFF to elution phase and due to participate of lead hydroxyl in basic $\mathrm{pH}$, the acidic $\mathrm{pH}$ was selected. Therefore, the acid solution can be used for back-extraction of lead from solid phase. The results demonstrated that the lead ions were simply back-extracted from SM@NGO adsorbent by nitric acid solution more than $0.4 \mathrm{~mol} \mathrm{~L}^{-1}$. Therefore, $0.5 \mathrm{~mol} \mathrm{~L}^{-1}$ of nitric acid $\left(\mathrm{HNO}_{3}\right)$ was used as optimum concentration of eluent for this study. Also, The results showed, the lead was efficiently back-extracted from SM@NGO by $0.5 \mathrm{~mL}$ of $\mathrm{HNO}_{3}$. Finally, the lead concentration in remained solution was determined with AT-FAAS after dilution with DW up to $1 \mathrm{~mL}$.

\subsubsection{Membrane filter reusing}

The reusability of the SM@NGO packed MillexFG hydrophobic PTFE membrane was evaluated by several extraction and elution cycles under optimized conditions. It was found that the membrane filter could be reused after backextraction processes and then rinsed by $5 \mathrm{~mL}$ of DW. The membrane filter was used for over 14 adsorption-elution cycles without significant decrease in extraction recoveries of lead ions. As collection adsorbent on membrane, the flow rate of eluent or samples through membrane filter was hardly done and so, the extraction recovery decreased more than 18 adsorption-elution cycles.

\subsubsection{Adsorption capacity}

The main parameter for evaluating of lead extraction with the SM@NGO packed MillexFG hydrophobic PTFE membrane is adsorption capacity. So, the adsorption capacity of $25 \mathrm{mg}$ of SM@NGO adsorbent for $\mathrm{Pb}$ (II) in $10 \mathrm{~mL}$ of human sample containing $5 \mathrm{mg} \mathrm{L}^{-1} \mathrm{~Pb}$ (II) ions was investigated at $\mathrm{pH} 6$ in static system. After adjusting $\mathrm{pH}$ with favorite buffer solution, the mixture was shaked for $15 \mathrm{~min}$ and filtered with Millex-FG hydrophobic PTFE membrane $(0.2 \mu \mathrm{m})$. Finally the residual concentrations of lead in the MillexFG hydrophobic PTFE membrane were determined using AT-FAAS. The adsorption capacities of GO and SM@NGO for Pb (II) ions were found to be $57.5 \mathrm{mg} \mathrm{g}^{-1}$ and $162.1 \mathrm{mg} \mathrm{g}^{-1}$, respectively.

\subsection{7.influence of Interference ions}

The influence of some coexisting ions for lead extraction in human samples was examined by the SF-D- $\mu$-SPE procedure. For investigation of the effect of different interference ions on lead extraction, the various ions $\left(0.5-2 \mathrm{mg} \mathrm{L}^{-1}\right)$ added to $10 \mathrm{~mL}$ of lead samples with $500 \mu \mathrm{g} \mathrm{L}^{-1}$ at $\mathrm{pH}$ 6.0. So, the most of the concomitant ions in human blood such as $\mathrm{Cu}, \mathrm{Zn}, \mathrm{Mn}, \mathrm{Mg}$, $\mathrm{Se}, \mathrm{Li}, \mathrm{F}, \mathrm{NO}_{3}, \mathrm{HCO}_{3}$, $\mathrm{Ca}, \mathrm{Na}$ an $\mathrm{K}$ were considered for lead extraction by SM@NGO adsorbent. The experimental results showed, the interference coexisting ions had no effect on lead extraction by proposed method. (Table1). Therefore, the SM@NGO adsorbent was efficiently extracted lead ions from human biological samples in the present of the interference coexisting ions.

\subsubsection{Determination of lead in real samples}

The SM@NGO adsorbent was used for extraction and determination of lead ions in human samples by the SF-D- $\mu$-SPE procedure. For validation of the results, the human blood, serum and plasma samples were spiked with lead standard solution based on SM@NGO nanostructure before determination by AT-FAAS. The high extraction of spiked samples demonstrated that the SM@ NGO adsorbent had satisfactory results for lead 
Table 1. The influence of interferences coexisting ions on lead extraction in human blood samples by the SF-D- $\mu$-SPE procedure

\begin{tabular}{lcc}
\hline & \multicolumn{1}{c}{$\begin{array}{c}\text { Mean ratio } \\
\left(\mathbf{C}_{\mathbf{I}} / \mathbf{C}_{\mathbf{P b}(\mathrm{II})}\right)\end{array}$} & Recovery (\%) \\
\cline { 2 - 3 } Interfering Ions & $\mathbf{P b}(\mathbf{I I})$ & $\mathbf{P b})$ \\
\hline $\mathrm{Cr}^{3+}, \mathrm{Se}^{2+}, \mathrm{Mn}^{2+}$, & 600 & 97.4 \\
$\mathrm{Zn}^{2+}, \mathrm{Cu}^{2+}$ & 700 & 98.6 \\
$\mathrm{I}^{-}, \mathrm{Br}^{-}, \mathrm{F}^{-}, \mathrm{Cl}^{-}$ & 1200 & 97.2 \\
$\mathrm{Na}^{+}, \mathrm{K}^{+}, \mathrm{Li}^{+}$ & 1000 & 99.2 \\
$\mathrm{Ca}^{2+}, \mathrm{Mg}^{2+}$ & 800 & 97.7 \\
$\mathrm{Ni}^{2+}, \mathrm{Co}^{2+}$ & 450 & 98.4 \\
$\mathrm{CO}_{3}^{2-}, \mathrm{PO}_{4}^{3-}, \mathrm{HCO}^{-}, \mathrm{NO}_{3}^{-}$ & 950 & 96.6 \\
\hline
\end{tabular}

extraction and determination in human samples at $\mathrm{pH}=6.0$ (Table 2). Also, $10 \mathrm{~mL}$ of the blood or serum samples were prepared from 50

workers of lead-acid batteries factories in India (Men, 20-55 age) by the SF-D- $\mu$-SPE procedure and compared to healthy peoples (Table 3). Moreover, the certified reference materials (NIST; CRM) and lead analysis with ICP-MS were used for validating of methodology based on SM@NGO by the proposed procedure (Table 4)

Table 2. Determination of lead based on SM@NGO adsorbent and spiking samples by the SF-D- $\mu$-SPE procedure coupled to AT-FAAS

\begin{tabular}{lccc}
\hline *Sample & Added $\left(\boldsymbol{\mu g} \mathbf{L}^{-1}\right)$ & *Found $\left(\boldsymbol{\mu g} \mathbf{L}^{-1}\right)$ & Extraction efficiency (\%) \\
\hline \multirow{2}{*}{ Blood } & --- & $9.7 \pm 224.2$ & --- \\
& 200 & $17.8 \pm 418.6$ & 97.2 \\
\hline \multirow{2}{*}{ Plasma } & --- & $2.8 \pm 55.4$ & --- \\
& 50 & $4.8 \pm 106.7$ & 102.6 \\
\hline \multirow{2}{*}{ Serum } & --- & $7.6 \pm 168.9$ & --- \\
& 150 & $14.3 \pm 311.6$ & 95.1 \\
\hline \multirow{2}{*}{ Blood } & --- & $8.2 \pm 178.8$ & --- \\
& 150 & $13.8 \pm 322.3$ & 95.6 \\
\multirow{2}{*}{ Serum } & --- & $9.4 \pm 192.3$ & --- \\
& 200 & $19.3 \pm 399.5$ & 103.6 \\
\hline \multirow{2}{*}{ Plasma } & --- & $4.2 \pm 88.5$ & -- \\
\hline
\end{tabular}

*Mean of three determinations of samples $\pm \mathrm{SD}(\mathrm{P}=0.95, \mathrm{n}=10)$ 
Table 3. Determination of lead in serum, blood and plasma by the SF-D- $\mu$-SPE procedure coupled to AT-FAAS (intra -day and inter day, $\mathrm{n}=50, \mu \mathrm{gL}^{-1}$ )

\begin{tabular}{|c|c|c|c|c|c|c|}
\hline \multirow{2}{*}{ "Sample } & \multicolumn{2}{|c|}{${ }^{\mathrm{b}}$ Workers $(\mathrm{n}=\mathbf{5 0})$} & \multicolumn{2}{|c|}{${ }^{\mathrm{b}}$ Healthy peoples $(\mathrm{n}=50)$} & \multicolumn{2}{|c|}{${ }^{a}$ Workers } \\
\hline & Intra-day & Inter day & Intra-day & Inter day & $\mathbf{r}$ & P value \\
\hline Blood & $352.8 \pm 15.7$ & $360.2 \pm 16.2$ & $33.1 \pm 1.4$ & $29.5 \pm 1.3$ & 0.092 & $<0.001$ \\
\hline Serum & $276.7 \pm 12.6$ & $281.2 \pm 13.9$ & $24.6 \pm 1.1$ & $28.2 \pm 1.2$ & 0.112 & $<0.001$ \\
\hline Plasma & $147.5 \pm 6.8$ & $152.4 \pm 7.3$ & $12.8 \pm 0.6$ & $14.6 \pm 0.7$ & 0.086 & $6<0.001$ \\
\hline
\end{tabular}

${ }^{\text {a }}$ Correlations are based on Pearson coefficients ( $\mathrm{r}$ ). Statistical significance will be observed if $\mathrm{P}<0.05$

${ }^{\mathrm{b}}$ Mean of three determinations of samples \pm confidence interval $(\mathrm{P}=0.95, \mathrm{n}=10)$

* 50 workers of lead-acid batteries factories in India (Men, 20-55 age)

Table 4. Validation of methodology for lead determination by certified reference materials(CRM, NIST)

\begin{tabular}{lcccc}
\hline Sample & CRM* $\left(\boldsymbol{\mu g ~ \mathbf { ~ L } ^ { - 1 } )}\right.$ & Added & Found $\left.^{*} \boldsymbol{\mu g ~ L ~}^{-1}\right)$ & Recovery (\%) \\
\hline Caprine blood, level 2 & $139.5 \pm 0.8$ & ----- & $135.8 \pm 6.5$ & 97.8 \\
\hline Caprine blood, level 3 & $277.6 \pm 1.6$ & ----- & ---- \\
\hline Serum by ICP-MS & & 200 & $272.6 \pm 13.1$ & 96.5 \\
\hline
\end{tabular}

${ }^{*}$ Mean of three determinations of samples $\pm \mathrm{SD}(\mathrm{P}=0.95, \mathrm{n}=10)$

CRM955c, caprine blood, level 2, $139.5 \pm 0.8 \mu \mathrm{g} \mathrm{L}^{-1}$

CRM955c, caprine blood, level 3, 277.6 $\pm 1.6 \mu \mathrm{g} \mathrm{L}^{-1}$

\section{Conclusions}

A novel SM@NGO adsorbent was used for lead separation/extraction in human blood, serum and plasma samples by the SF-D- $\mu$-SPE coupled to AT-FAAS. The Millex-FG hydrophobic PTFE membrane $(0.2 \mu \mathrm{m})$ was used as a filter for separating solid phased from liquid phase. By the SF-D- $\mu$-SPE method, the high extraction, the low cost, the fast separation and simple method in short time was obtained in optimized $\mathrm{pH}$. The trace amount of SM@NGO as a solid-phase caused to extract the lead ions from the human biological samples without any ligand. The developed SF-D- $\mu-$
SPE method presented a analytical nanotechnology for lead separation/extraction/preconcentration in human blood samples with low interference ions, good reusability and simple sample preparation in difficulty matrixes. Therefore, the SM@NGO nanostructure was used as a perfect adsorbent for determination and extraction of lead in blood, serum and plasma samples by AT-FAAS.

\section{Acknowledgments}

The authors wish to thank from Department of Chemistry, Hi Tech institute of theoretical and computational chemistry, India 


\section{References}

[1] S. Morais, F.G. Costa, M.L. Pereira, Heavy metals and human health, Intech publisher, pp. 227-246, 2012.

[2] K. Rehman, F. Fatima, I. Waheed, Prevalence of exposure of heavy metals and their impact on health consequences, J. Cell. Biochem., 119 (2018) 157-184.

[3] F. Zhushan, X. Shuhua, The effects of heavy metals on human metabolism, Toxicol. Mech. Meth., 30 (2020) 167-176.

[4] W. Liu, J.P. Tian, L.J. Chen, Y. Guo, Temporal and spatial characteristics of lead emissions from the leadacid battery manufacturing industry in China, Environ. Pollut., 220 (2017) 696-703.

[5] P.V. Bossche, F. Vergels, J.V. Mierlo, J. Matheys, W.V. Autenboer, An assessment of sustainable battery technology, J. Power Sources, 162 (2006) 913-919.

[6] A.1. Wani, A. Ara, J.A. Usmani, Lead toxicity: A review, Int. Toxicol., 8 (2015) 55-64.

[7] J.w. Lee, H. Choi, U.K. Hwank, J.C. Kang, Y.J. Kang, K.I. Kim, J.H. Kim,. Toxic effects of lead exposure on bioaccumulation, oxidative stress, neurotoxicity, and immune responses in fish: A review, Environ. Toxicol. Pharmacol., 68 (2019) 101-108. [

[8] Lead toxicity, what Is the biological fate of lead in the body, environmental health and medicine education, Agency for toxic substances and disease registry (ATSDR), 2017. https://www. atsdr.cdc.gov/csem $/$ csem. aspcsem $=34 \& p o=9$

[9] M. Giel-Pietraszuk, K. Hybza, M. Chełchowska, J. Barciszewski, Mechanisms of lead toxicity, Adv. Cell Biol., 39 (2012) $17-$ 248.

[10] M. Irberger, J.J. Yang, Structural differences between $\mathrm{Pb}^{2+}$ - and $\mathrm{Ca}^{2+}$-binding sites in proteins: implications with respect to toxicity, J. Inorg. Biochem., 102 (2008) 1901-1909.

[11] Elemental impurities guidance for industry, department of health and human services, food and drug administration (FDA), 2017.

[12] Atlanta centers for disease control (ACDC), US department of health and human services, national institute for occupational safety and health (NIOSH), Adult blood lead epidemiology and surveillance (ABLES), 2017.

[13] R.A. Zounr, M. Tuzen, M.Y. Khuhawar, A simple and green deep eutectic solvent based air assisted liquid phase microextraction for separation, preconcentration and determination of lead in water and food samples by graphite furnace atomic absorption spectrometry, J. Mol. Liq., 259 (2018) 220-226.

14] J.S. Mandlate, B.M. Soares, T.S. Seeger, P.D. Vecchia, P.A. Mello, E.M.M. Flores, F.A. Duarte, Determination of cadmium and lead at sub-ppt level in soft drinks: An efficient combination between dispersive liquid-liquid microextraction and graphite furnace atomic absorption spectrometry, Food Chem., 221 (2017) 907-912

[15] M.A. Habila, Z.A. AlOthman, M. Soylak, Fe3O4nanoparticles and ultrasound assisted dispersive liquid-liquid microextraction of lead(ii) for its microsampling flame atomic absorption spectrometric determination in food and environmental samples, RSC Adv., 4 (2014) 55610-55614.

[16] M.A. Habila, Z.A. ALOthman, A.M. ElToni, J.P. Labis, X. Li, F. Zhang, M. Soylak, Mercaptobenzothiazole-functionalized magnetic carbon nanospheres of type $\mathrm{Fe}_{3} \mathrm{O}_{4} @$ $\mathrm{SiO}_{2} @ \mathrm{C}$ for the preconcentration of nickel, copper and lead prior to their determination by ICP-MS, Microchim. Acta, 183 (2016) $2377-$ 2384.

[17] M. García, M. Ángel Aguirre, A multinebulization technique for the determination of trace metals in a marine biota sample by on-line isotope dilution inductively coupled plasma mass spectrometry (OID-ICPMS), J. Anal. At. Spectrom., 35 (2020) 25092516.

[18] Y. Yamini, M. Rezazadeh, S. Seidi, Liquidphase microextraction-The different principles and configurations, Trends Analyt Chem., 112 (2019) 264-272.

[19] S.Z. Mohammadi, T. Shamspur, Y.M. Baghelani, Combination of flame atomic absorption spectrometry with ligandlessdispersive liquid-liquid microextraction for preconcentration and determination of trace 
amount of lead in water samples, Bull. Chem. Soc. Ethiop., 27 (2013) 161-168.

[20] P. Makoś, E. Słupek, J. Gębicki, Hydrophobic deep eutectic solvents in microextraction techniques-A review, Microchem. J., 152 (2020) 104384.

[21] C. Zheng, L. Hu, X. Hou, B. He, G. Jiang, Headspace solid-phase microextraction coupled to miniaturized microplasma optical emission spectrometry for detection of mercury and lead, Anal. Chem., 90 (2018) 3683-3691.

[22] L. Alavi, S. Seidi, A. Jabbari, T. Baheri, Deep eutectic liquid organic salt as a new solvent for carrier-mediated hollow fiber liquid phase microextraction of lead from whole blood followed by electrothermal atomic absorption spectrometry. New J. Chem., 41 (2017) 70387044.

[23] M. Sadeghi, E. Rostami, D. Kordestani, H. Veisi, M. Shamsipur, Simultaneous determination of ultra-low traces of lead and cadmium in food and environmental samples using dispersive solid-phase extraction (DSPE) combined with ultrasound-assisted emulsification microextraction based on the solidification of floating organic drop (UAEME-SFO) followed by GFAAS, RSC Adv., 7 (2017) 2765627667.

[24] E. Koosha, M. Shamsipur, F. Salimi, M. Ramezani, A microextraction method based on precipitation for the simultaneous separation and preconcentration of cadmium and lead before their determination by FAAS: Experimental design methodology, Sep. Sci. Technol., 56 (2020) 1-9.

[25] E. Zolfonoun, Solid phase extraction and determination of indium using multiwalled carbon nanotubes modified with magnetic nanoparticles, Anal. Methods Environ. Chem. J., 1 (2018) 5-10.

[26] H.R. Sobhi, A. Mohammadzadeh, M. Behbahani, A Implementation of an ultrasonic assisted dispersive $\mu$-solid phase extraction method for trace analysis of lead in aqueous and urine samples, Microchem. J., 146 (2019) 782-788.

[27] M. Falahnejad, H.Z. Mousavi, H. Shirkhanloo, A. Rashidi, Preconcentration and separation of ultra-trace amounts of lead using ultrasoundassisted cloud point-micro solid phase extraction based on amine functionalized silica aerogel nanoadsorbent, Microchem. J., 125 (2016) 236-241.

[28] E. Yilmaz, R.M. Alosmanov, M. Soylak, Magnetic solid phase extraction of lead(ii) and cadmium(ii) on a magnetic phosphoruscontaining polymer (M-PhCP) for their microsampling flame atomic absorption spectrometric determinations, RSC Adv., 5 (2015) 33801-33808.

[29] Y. Wang, H. Chen, J. Tang, G. Ye, H. Ge, X. $\mathrm{Hu}$, Preparation of magnetic metal organic frameworks adsorbent modified with mercapto groups for the extraction and analysis of lead in food samples by flame atomic absorption spectrometry, Food Chem., 181 (2015) 191197.

[30] M. Rosillo-Lopez, C. Salzmann, Highly efficient heavy-metal extraction from water with carboxylated graphene nanoflakes, RSC Adv., 8 (2018) 11043-11050.

[31] A. slam, H. Ahmad, N. Zaidi, S. Kumar, Graphene oxide sheets immobilized polystyrene for column preconcentration and sensitive determination of lead by flame atomic absorption spectrometry, ACS Appl. Mater. Interfaces, 6 (2014) 13257-13265.

[32] A. Ensafi, S. Rabiei, B. Rezaei, A. Allafchian, Magnetic solid-phase extraction to preconcentrate ultra trace amounts of lead(ii) using modified-carbon nanotubes decorated with $\mathrm{NiFe}_{2} \mathrm{O}_{4}$ magnetic nanoparticles, Anal. Methods, 5 (2013) 3903-3908.

[33] C. Botas, P. lvarez, P. Blanco, M. Granda, C. Blanco, R. Santamar, L. J. Romasanta, R. Verdejo, M. A. L. pez-Manchado, R. Menndez, Graphene materials with different structures prepared from the same graphite by the Hummers and Brodie methods, Carbon, 65 (2013) 156-164.

[34] Z.B. Liu, Y.F. Xu, X.Y. Zhang, X.L. Zhang, Y.S. Chen, J.G. Tian, Porphyrin and fullerene covalently functionalized graphene hybrid materials with large nonlinear optical properties, J. Phys. Chem. B, 113 (2009) 96819686 